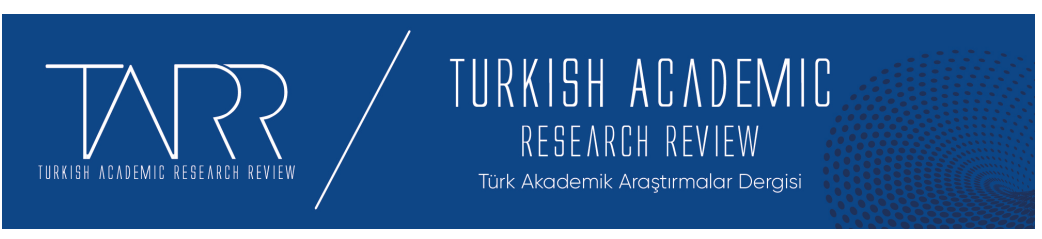

e-ISSN: 2602-2923 Yıl/Year: 2021 Cilt/Volume: 6 Sayı/Issue: 2

\title{
Alkol Bağımlılığıyla Baş Etmede Manevi Bakım İhtiyaçlarının Belirlenmesi
}

Determination of the Spiritual Care Needs in the Coping with Alcohol Addiction

\section{İsa CEYLAN - Abdullah DAĞCI}

Dr., TRT Genel Müdürlüğ̈̈, ceylanisa@gmail.com, Orcid ID: 0000-0002-6163-5689

Dr., Karamanoğlu Mehmetbey Üniversitesi, adagci@kmu.edu.tr, Orcid ID: 0000-0003-15401256

\begin{tabular}{r|l} 
Makale Bilgisi & Article Information \\
Makale Türü - Article Type & Araştırma Makalesi / Research Article \\
Geliş Tarihi - Date Received & 17 Mart / March 2021 \\
Kabul Tarihi - Date Accepted & 23 Haziran / June 2021 \\
Yayın Tarihi - Date Published & 25 Haziran / June 2021 \\
Yayın Sezonu & Nisan - Mayıs- Haziran \\
Pub Date Season & April - May - June
\end{tabular}

Atıf/Cite as: Ceylan, İ.-Dağcı, A. (2021). Alkol Bağımlılığıyla Baş Etmede Manevi Bakım İhtiyaçlarının Belirlenmesi/Determination of the Spiritual Care Needs in the Coping with Alcohol Addiction. Turkish Academic Research Review, 6 (2), 397416. Retrieved from https://dergipark.org.tr/tr/pub/tarr/issue/62824/898342

Intihal / Plagiarism: Bu makale, en az iki hakem tarafından incelenmiş ve intihal içermediği teyit edilmiştir. / This article has been reviewed by at least two referees and confirmed to include no plagiarism. https://dergipark.org.tr/tr/pub/tarr

Copyright (C) Published by Mehmet ŞAHIN Since 2016- Akdeniz University, Faculty of Theology, Antalya, 07058 Turkey. All rights reserved.

Turkish Academic Research Review - Türk Akademik Araştırmalar Dergisi 


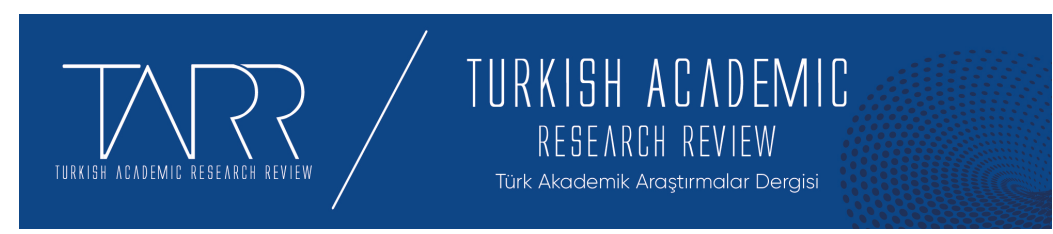

e-ISSN: 2602-2923 Yll/Year: 2021 Cilt/Volume: 6 Sayı/Issue: 2

\title{
Alkol Bağımlılığıyla Baş Etmede Manevi Bakım İhtiyaçlarının Belirlenmesi
}

\author{
İsa CEYLAN - Abdullah DAĞCI
}

\begin{abstract}
$\ddot{O} z$
$\mathrm{Bu}$ çalışmanın amacı, maneviyat fenomeni çerçevesinde alkol bağımlısı bireylerin deneyimledikleri dini ve manevi yaşantıların, kendileri için ne ifade ettiğini ve ne anlama geldiğini araştırmaktır. Diğer yandan maneviyatın bilinçli deneyimler üzerinden ne şekilde algılanıp yorumlandığı ve bu yorumların ortak yönlerinin neler olduğunun keşfedilmesi hedeflenmiştir. Araştırmada nitel araştırma deseni kullanılmıştır. Çalışmaya katılan bireylerin tecrübeleri, maneviyata yükledikleri işlevsel anlamlar ve öz deneyimler ortaya konulmaya çalışılmıştır. Bu çerçevede ifade edilen duygular ve yaşantılar, betimleyici fenomenolojik analiz ile çözümlenerek yorumlanmıştır. Böylelikle elde edilen bulguların alkol bağımlılığıyla baş etmeye çalışan bireylere yönelik uygulanabilecek manevi bakım süreçlerine katkı sağlayacağı düşünülmektedir. Çalışma grubu, Alkol ve Madde Bağımlılığı Tedavi ve Eğitim Merkezi'nde (AMATEM) alkol kullanım bozukluğu tanısı konulan ve çalışmaya katılmaya gönüllü olan 5 kişiden oluşmaktadır. Yarı açık uçlu 10 soruya verilen cevapların tematik analizi sonucunda "dini ritüeller, af olgusu, yaşam sistemindeki İlahî tasarım inancı "kader", duygulart kontrol etme "nefs yönetimi”, sosyal destek almak, aile bağlarl, ruhsal ve psikolojik değişimler "gelgitler yaşamak", tövbe deneyimi, paranormal inançlara atıflar" başlıklı temalara ulaşılmıştır. Sonuç olarak alkol bağımlıları, uygulanan ritüellere ve paylaşılan ortak anlamlara açıkça inandıkları sürece bağımlılığı kontrol altına almada fayda görebileceklerini iletmişlerdir.
\end{abstract}

Anahtar kelimeler: Manevi Bakım, Alkol Bağımlılığı, Dini/Manevi Baş Etme, İhtiyaç Analizi, Fenomenoloji.

\begin{abstract}
The aim of this study is to determine what the religious and spiritual experiences of alcohol addicted individuals within the framework of spirituality phenomenon express and what they mean for them. How spirituality is perceived and interpreted through conscious experiences; it was also aimed to discover what the common aspects of these comments are. Qualitative research design was used in the research. The experiences of the individuals participating in the study, the functional meanings and self-experiences they attribute to spirituality were tried to be revealed. Emotions and experiences expressed in this framework were analysed and interpreted with descriptive phenomenological analysis. Thus the obtained findings will contribute to the spiritual care processes that can be given to individuals who are trying to cope with alcohol addiction. The study group consists of 5 volunteered people who were applied to the Alcohol and Substance Addiction Treatment and Training Centre (AMATEM) and diagnosed with a diagnosis of alcohol use disorder. As a result of the thematic analysis of the answers given to 10 semi-openended questions, themes consisting of various factors such as "religious rituals, the fact of forgiveness, belief in Divine design in the life system (fate), controlling the emotions (managing the psyche), getting social support, family ties, psychological mood swings (tides), repentance experience, references to paranormal beliefs" were reached. As a result, alcohol addicts stated that they could benefit from controlling
\end{abstract}

Turkish Academic Research Review - Türk Akademik Araştırmalar Dergisi 
addiction as long as they clearly believed in the rituals and shared common meanings.

Keywords: Spiritual Care, Alcohol Addiction, Religious/Spiritual Coping, Need Analysis, Phenomenology.

\section{Structured Abstract}

It's said that drinking buffers and acts as a coping mechanism against stress by the people with alcohol use disorder. It is generally accepted that people drink alcohol to cope with the effects of stress. In processes that can increase the stress levels of individuals, such as the Covid-19 epidemic, it becomes difficult to cope with the problems brought by life events. In this context, religion and spirituality significantly affect emotions, thoughts and behaviours in experienced events. The present study was carried out during the Covid-19 epidemic covering the years 2020-2021. The problem of this study is whether religious/spiritual coping skills, which are frequently used in spiritual care practices, can contribute to coping with alcohol addiction.

The aim of the study

In this study, it is suggested that individuals are more vulnerable in terms of psychological health conditions, stress management and alcohol use, especially in extraordinary situations such as epidemics. In this context, it is aimed to determine the spiritual needs of alcohol addicts in coping with risk factors such as stress and to develop suggestions for spiritual practices.

Method:

How spiritual needs are perceived and interpreted through conscious experiences and the common aspects of shared interpretations have been tried to be discovered by content analysis and descriptive analysis. It has been tried to reveal the experiences of the participants and especially the functional meanings they attribute to spirituality. For this reason, the focus is on the self-experiences of individuals. The emotions and experiences of the participants were evaluated and interpreted within the framework of spirituality and spiritual care approaches.

Discussion:

Emergency situations are a special period in which needs arise such as "creating an interdisciplinary psychological health team, providing psychiatric treatments and other health services, making use of online spiritual care platforms, establishing rehabilitation programs, providing specific care to vulnerable groups".

Special needs that arise around the phenomenon of forgiveness, such as forgiveness and being able to forgive, are also considered within the scope of spiritual needs by the participants. The dilemmas experienced in the mental and emotional background related to these shared themes are issues that are waiting to be resolved and are largely related to spirituality.

According to the statements of the participants, learning to manage emotions is actually learning "nafs training". The discipline of the nafs can be possible by exhibiting certain rituals and behaviours. It can be said that recognizing the emotions that play a guiding role in the inner world of the individual is an important step in controlling alcohol addiction. Because an emotion that is named and recognized can be managed better. Alcohol consumption serves the two most basic desires of the soul, such as being happy and escaping from pain. In this framework, the idea of "spiritual taste" and the "value of patience" that support coping skills can be included in spiritual care work.

For respondents who report frequently experience tides, the goal of longterm abstinence from alcohol is not always achievable. In this context, increasing the 
intervals of abstinence from alcohol can be considered among short-term small solutions. In this context, the concept of "istighfar (praying for forgiveness)" in Islamic thought can contribute to coping processes by positively affecting the frequency and duration of these short intervals.

Sice the thought of transformation from one state to another (tawba/repentance) of the addicted individual in his journey to stay away from alcohol can be considered within the scope of worship. Thus, he can attribute a spiritual meaning to every emotion, thought and action without making any material or spiritual discrimination, and he can live a continuous spiritual life with the intention of repentance.

Likewise, the prohibition of alcoholic beverages in the religion of Islam is for the protection of one's mind, property, progeny and life and to respect them (Maide, 5:90-91). With the verse in question in the Qur'an, attention is drawn to the need to stay away from alcohol and the importance of protective approaches towards alcohol addiction.

It is known that mystical delusions are often caused by a lack of insight. These paranormal beliefs can reduce the sense of responsibility, increase mystical delusions. In this context, it is thought that evidence-based data should be used in spiritual care studies.

Result:

Themes such as "religious rituals, the fact of forgiveness, belief in Divine design in the life system (fate), controlling the emotions (managing the psyche), getting social support, family ties, psychological mood swings (tides) repentance experience, references to paranormal beliefs" were reached. The themes that emerged after the descriptive phenomenological analysis of the findings obtained can be evaluated as "spiritual needs", and can use in spiritual care practises.

\section{Giriş}

2020 yılı Şubat ayı bitiminde koronavirüs (COVID-19) birçok ülkeye yayıldı. İlk vakalarının görülmeye başlandığı zamanın üzerinden yaklaşık 1 sene geçti. $\mathrm{Bu}$ süreçte salgını kontrol altına alma girişiminde, dünyanın dört bir yanından hükümetler tıbbî önlem arayışları sırasında sosyal veya fiziksel mesafe önlemleri uyguladı. Diğer yandan bu durum milyonlarca insanın uzun süre evlerinde izole edilmesine neden oldu. Türkiye Hükümeti COVID-19 salgını sırasında halka evde kalmalarını, gereksiz sosyal temastan kaçınmalarını ve kendilerini korumalarını salık verdi. Belli dönemlerde ise dışarı çıkma yasağı uygulandı (Akgün, 2020).

Birçok ülkede devam eden sokağa çıkma yasakları sağlık ve esenlik açısından genel popülasyon üzerinde olumsuz etkiler üretmektedir. Son 1 sene içerisinde anksiyete, depresyon ve alkol bağımlılığının yaygınlık oranı endişe verici boyuta gelmiştir. Ayrıca tecrit ve yaygın ekonomik zararlar, birçok insanın psikolojik olarak stres ve kaygı bozukluğu gibi rahatsızlıklar yaşamasına neden olmuştur. $\mathrm{Bu}$ stres ve kaygı, alkol kullanımının başlangıcı ve sürdürülmesi anlamında önemli bir risk faktörüdür. Kronik alkol kullanımı bir yandan bağışıklık sisteminin düzensizliğine ve duygusal düzenlemelerde sorunlara; diğer yandan hem zihinsel sağlık bozukluğuna hem de ödül yollarında bozulmalara neden olmaktadır.

Turkish Academic Research Review - Türk Akademik Araştırmalar Dergisi 
Beyindeki nöro-adaptasyonlar ise strese yanıt olarak alkol için artan istekliliğe yol açmaktadır. Bu kapsamda uzun vadeli sosyal izolasyonun, artan sinirsel ve hormonal yanttlar ile stres seviyeleri üzerindeki etkileri bilinmektedir (Clay \& Parker, 2020). Dolayısıyla, bu tecrit dönemi risk altındaki bireylerde alkol kullanımında artışa, nüksetmeye ve potansiyel olarak alkol bağımlılı̆̆ının gelişmesine neden olabilir.

Covid-19 salgını sırasında alkol tüketimine yönelik yapılan akademik çalışmalarda katılımcılar, salgının başlangıcından sonra alkol tüketimini artırdıklarını dile getirmişlerdir. Salgın sırasında alkol alımını artıran dolayısıyla alkole bağlı sorunlara karşı savunmasız olan katılımcılar, alkole başladıkları için zihinsel sağlık açısından daha kötü duruma geldiklerini ve acı çektiklerini ifade etmişlerdir. Ayrıca alkol kullanıcıları streslerini yönetmek ve hafifletmek için salgın öncesi denenmiş bir yol olarak alkol kullanmaya yöneldiklerini belirtmişlerdir (Chodkiewicz, 2020). Bu bağlamda uzun süreli izolasyonun alkol kullanımı ve alkol bağımlılığı üzerindeki potansiyel riskleri üzerine oldukça fazla sayıda akademik araştırma bulunmaktadır (Calina, 2021; Clay \& Parker, 2020; de Backer, 2021; Knopf, 2020).

Salgın zamanında alkol kullanımını azaltmak veya önlemek için risk faktörlerini en aza indirecek ve koruyucu faktörleri en üst düzeye çıkaracak hizmetler ve programlar sunma ihtiyacı gün yüzüne çıkmaktadır (Lechner vd., 2020). Söz konusu uygulamalardan olan manevi bakım çerçevesinde dini/manevi başa çıkma becerileri hem sıklıkla bireylerin alkol ve diğer bağımlılık yapıcı maddelerin kullanımını kontrol altına almaya hem de bağımlılıktan arınmaya önemli katk1 sağlayan unsurlar olarak kabul edilmektedir. Dolayısıyla zihinsel rahatlama sağlamak (Fardin, 2020) için uygun yöntemlerden birinin manevi bakım olduğu söylenebilir. Diğer yandan dinler, kriz zamanlarında insanlığa manevi açıdan yardımcı olmak için davranışsal tavsiyeler vermektedirler.

\section{Yöntem}

Bu çalışmanın amacı; maneviyat fenomeni çerçevesinde alkol bağımlısı bireylerin deneyimledikleri dini ve manevi yaşantıların kendileri için ne ifade ettiğini ve ne anlama geldiğini araştırmaktır. Ayrıca maneviyatın bilinçli deneyimler üzerinden ne şekilde algılanıp yorumlandığının ve bu yorumların ortak yönlerinin neler olduğunun keşfedilmesi de hedeflenmiştir. $\mathrm{Bu}$ açıdan araştırmada nitel araştırma deseni kullanılmıştır.

Paylaşılan manevi ihtiyaçların ortak tarafları içerik analizi ve betimleyici analiz ile keşfedilmeye çalışılmıştır. Katılımcı bireylerin deneyimleri ve özellikle 
maneviyata yükledikleri işlevsel anlamlar ortaya konulmaya çalışılmıştır. $\mathrm{Bu}$ nedenle kişilerin yaşadıkları öz deneyimlere odaklanılmıştır. Katılımcıların duyguları ve yaşantıları, maneviyat ve manevi bakım yaklaşımları çerçevesinde değerlendirilerek yorumlanmıştır.

\section{Problem ve cevap aranan sorular}

Özellikle Covid-19 salgını gibi bireylerin stres düzeylerini artırabilen süreçlerde yaşam olaylarının getirdiği sorunlarla başa çıkmak zorlaşmaktadır. $\mathrm{Bu}$ çerçevede din ve maneviyat deneyimlenen yaşam olaylarında duygu, düşünce ve davranışları belirgin bir şekilde etkilemektedir. Bu bağlamda mevcut çalışma 20202021 yıllarını kapsayan Covid-19 salgını sırasında gerçekleştirilmiştir. Manevi bakım uygulamalarında sıklıkla kullanılan dini/manevi başa çıkma becerilerinin alkol bağımlılığıyla baş etmeye katkı sunup sunamayacağı bu çalışmanın problemini teşkil etmektedir.

Covid-19 salgını ile alkol kullanım davranışı arasındaki ilişkiyi gösteren birçok çalışma vardır (Calina, 2021; Clay \& Parker, 2020; de Backer, 2021; Knopf, 2020). Dolaylstyla söz konusu ilişkiyi ortaya koymaktan öte; benzer olağanüstü durumların gün yüzüne çıkardĭ̆ı alkol bağımlıllğg riskine yönelik geliş̧tirilebilecek manevi bakım uygulamalarının içeriği için bir ihtiyaç analizi yapma gereksinimi doğmuştur. Bu çerçevede çalışmada aşağıdaki sorulara cevaplar aranmıştır:

Alkol bağımlılığıyla baş etmede özellikle alkol bağımlısı bireylerin deneyimledikleri manevi görüngüler nelerdir?

- Deneyimlenen manevi fenomenlere yüklenen anlamların baş etmeye katkısı nasıldır?

- $\quad$ Tespit edilen temaların manevi bakım uygulamalarında kullanılma imkânı nedir?

\section{Çalıșma Grubu}

Çalışma grubu, Alkol ve Madde Bağımlılığı Tedavi ve Eğitim Merkezi'nde (AMATEM) alkol kullanım bozukluğu tanısı alan ve çalışmaya katılmaya gönüllü olan 5 kişiden oluşmaktadır. Fenomenolojik modelde, araştırmaya katılan bireylerin deneyimleri üzerinden veriler üretildiğinden, katılımcıların sosyolojik ve psikolojik niteliklerine dönük ifadeleri de dikkate alınmıştır. $\mathrm{Bu}$ nedenle araştırmaya katılanlar, nitel çalışmalarda sıklıkla tercih edilen "amaçlı örnekleme (purposive sampling)" yöntemlerinden "kritik durum" örneklemesiyle seçilmiştir (Yıldırım ve Şimşek, 2016: 121). Araştırmaya katılanların hepsi erkektir ve yaş ortalamaları 41,80'dir. Katılımcılar 'K1 (40 yaş), K2 (34 yaş), K3 (48 yaş),

Turkish Academic Research Review - Türk Akademik Araştırmalar Dergisi https://dergipark.org.tr/tr/pub/tarr 
K4 (46 yaş), K5 (41 yaş)" şeklinde kodlanmıştır. Görüşmelerin her biri ortalama 25 dakika sürmüştür.

\section{Verilerin Toplanması ve Analizi}

Ses kayıtları yoluyla elde edilen veriler bilgisayar ortamında deşifre edilmiş ve ardından NVivo 10 paket programıyla veriler kodlanmış ve çözümlenmiştir. Çalışmaya katılan bireylerin ifade ettiği yaşantılar, duygular, maneviyata yükledikleri işlevsel anlamlar ve öz deneyimlere ilişkin temalar ortaya konulmaya çalışılmıştır. Söz konusu temalar; araştırma soruları, dini baş etme ve manevi bakım yaklaşımları bağlamında öngörülerde bulunulması, görüşmeler sonrasında doğrulanan temalarla birlikte yeni temaların da keşfedilmesi amacıyla betimleyici fenomenolojik analiz ve içerik analizi tekniği ile çözümlenmiştir. Böylelikle elde edilen bulgular alkol bağımlılığıyla baş etmeye çalışan bireylere yönelik verilebilecek manevi bakım süreçlerine katkı sağlayabileceği düşünülmektedir.

\section{Bulgular}

Alkol bağımlısı bireylerle yapılan görüşmelerde maneviyatın nasıl deneyimlendiğine odaklanılmıştır. Görüşmeler sırasında maneviyat ile ilgili konuşulduğunda genellikle dini ritüellerin, aile bağlarının, affedilme istekliliğinin ön plana çıktığı görülmüştür. Ayrıca alkol kullanımını tetikleyebilen veya çağrıştırabilen deneyimlerden sonra gelgitler yaşama, duyguları kontrol edip yönetme ve sosyal destek alma hususları da dile getirilmiştir. Bunlara ek olarak tövbe deneyimleri ve Ilahî bir tasarım inancı (kader) ile paranormal inançlara atıflar da maneviyat çerçevesinde iletilen diğer fenomenlerdendir. Görüşme kayıtlarından elde edilen bulgular dinî inançları da içine alan maneviyat görüngüsü çerçevesinde içerik analizine tabi tutulup fenomenolojik desene göre temalarına ayrılarak yorumlanmıştır.

\section{Dini Ritüeller}

Dini ritüeller, maneviyat fenomenine ilişkin olarak en çok dillendirilen temadır. Özellikle dua, namaz, Kur'ân-1 Kerim okumak, dinî bilgiler öğrenmek bunların başında gelmektedir. Dini ritüeller bağlamında İslam dininin emrettiği abdest alma, namaz kılma, kutsal mekân ziyaretleri gibi ibadetleri yerine getirmenin alkol bă̆ımlılı̆̆ını kontrol etmede önemli bir kaynak olduğu, alkol bağımlılı̆̆ına yönelik nüks yaşama riskini azalttı̆̆ını vurgulayan katılımcılar duygusal ve ruhsal açıdan da rahatlama yaşadıklarını belirtmişılerdir. Bu bağlamda bir katılımcı kızıyla beraberliği sırasında namaz kılma ve Kur'an okuma ibadetine ilişkin diyaloglarını şu 
şekilde paylaşmıştır: "12 yaşında küçük bir kızım var. Beni evde namaz kılarken görüyor. Baba ben de namaz kllabilir miyim diyor. Ayrıca din kültürü ve ahlak bilgisi dersi alıyorlar. Biz sureleri yavaş yavaş çallşıyoruz, ben akşamları yatarken çalıștırıyorum" (K3). Aynı katılımcı alkol bağımlılığına giden süreçte geçirdiği yaşam serüvenini namazla ilişkilendirerek aktarmıştır. Namazın alkole başlama ve alkol bağımlısı olma sürecini oldukça geciktirdiğini, namazın kendisini tuttuğunu belirtmiştir. Namaz kılmayı yavaş yavaş bıraktıktan ve daha seküler bir yaşam tarzına sahip olduktan sonra alkol bağımlılığına giden yolun önünün açıldığını ifade etmiştir:

"Üniversiteye başlamadan önce beş vakit namazın kilan bir insandım, gençlikte de öyleydim. Teravihimizi kaçırmazdlk mesela. Yani inanç konusunda altyapım sağlamdır. Bir insanın sorumluluk ve görevleri ile Yaradan'ina karşı ne yapması gerektiği, yaratılış gayesinin ne olduğu, Allah'ın kulların kendisine ibadet etsinler diye yarattığı düşünceleri vs. hepsi daha o zamanlarda vard. Üniversite ilk sinifta evlerinde kaldiğım arkadaşların da etkisi ile siyasi çizgiler oluşmaya başlayınca topluma bakış açısı biraz daha sola kaydl. Dolayısıyla ben eski dini yaşamımdan uzaklaştım. Önce vakitleri erteledik. Kazaya birakttk. Sonra kazaları da erteledik derken kısacası neredeyse tamamı ile uzaklaştık bir dönem..."

(K3)

Alkol kullanımına neden olabilen stres, kayg1, üzüntü gibi duygulara yönelik olarak abdest almanın kendisini rahatlattığını (K1) belirten bir katılımcı namaz kılmanın da kendisini kuş gibi hafiflettiğini belirtmektedir. Bu çerçevede başka bir katılımcı ibadetlerin kendisine manevi anlamda büyük keyif verdiğine "Böyle bir dua ettim. Namaza da başladım. Kur'an'1 okuyorum, anlamını. Kur'an kursuna başladım. 15 günde heceleye heceleye Kur'an okumaya başladım. Camide dersler var. Camiden çıkmıyorum yani. Bir de anlamlarını bir de ilmek ilmek yani. O kadar çok zevk alıyorum ki” (K5) sözleriyle işaret etmektedir.

\section{Af Olgusu}

Bazı katılımcılar geçmişte yakınlarıyla kurdukları iletişim ve ilişki sırasında deneyimledikleri öfke, klzgınlık/kirgınlık ve suçlama gibi yaşantıların şimdiki duygularını olumsuz yönde etkilediğini sözlerine eklemektedir. Bir katılımcı "Allah sizi inandırsın affedemediğim bir tek o şahıs var. İçimde devaml onu suçluyorum. Kin vs. adını ne koyarsanız koyun. İçinizde bir negatiflik var" sözleriyle öfkesinin kendisini olumsuz etkilediğini, affa konu olan meselenin çözülmediğinde geleceğin de çözülemediğini (K3) belirtmiş̧tir. Öfkeyi, insanın içinde ve atılması

Turkish Academic Research Review - Türk Akademik Araştırmalar Dergisi https://dergipark.org.tr/tr/pub/tarr 
gereken bir zehir (K3) olarak betimleyen kat1lımc1 affetmenin bu zehrin atılmasının aracı olduğunu söylemektedir. Affı ümit bağlamında ele alan katılımcı “AMATEM'in mescidinin girişinde yazan Allah affedicidir, Allah'tan ümit kesilmez. Allah'tan ümidini kesenler kâfirlerdir" ayetini mescide hem girerken hem oradan çıkarken okuduğunu (K3) dile getirmiştir.

Bazı katılımcılar öncelikle kendileriyle barışamadıkları sürece ne bu dünya ne de öbür dünya ile barışamadıklarını belirtmişlerdir. Kendiyle barışma bağlamında af olgusunu ele alan katılımcılar ancak bu şekilde kendilerinde yaşamayı hak ettikleri inancının oluşabildiğini ve kendilerine değer verebildiklerini iletilmişlerdir (K2, K3). Bir katılımcı affolunma ihtiyacına ilişkin olarak, "Kurban olduğum Yaradan'ımın bana verdiği değerin bir kısmını ben fark edebilsem kendi adıma... Kendinin çok değerli bir varlık olduğunu, güzel şeyler yaşamaya muktedir olduğunu, hak ettiğini ya da yaşaması gerektiğini düşünüyor insan. En zoru kendimizi affetmek" (K3) şeklinde ifadelerde bulunarak Yaradan tarafindan affolunmanın değerlilik hissini artırdığını dile getirmiştir.

Allah'ın affediciliğini nefse zulmetmeme ve Yaradan'a dönüş açısından ele alan başka bir katılımcı yakın çevresine yaptığı haksızlıkların sonucu olarak suçluluk duyguları hissettiğini belirtmektedir: "Allah nefsinize zulmetmeyin diyor, bana dönün diyor. Ben kendime, arkadaş çevreme, anne babama eşime çocuklarıma zulmettim. Annem babam daha önce affettiler. Sonra sevindiler. Sonra onlart geri üzdüm" (K4). Başka bir katılımcı da benzer biçimde nefsinin istek ve arzuları yüzünden bağımlılıkla geçen hayatının hiçbir olumlu çıktısının olmadığını ve affolunmak için nefsini Allah'a şikâyet ettiğini (K1) dile getirmiştir.

Başka bir bağımlı birey babasının vefatından yaklaşık 1 sene sonra 15 yaşlarında iken çok sevdiği ve bağlı olduğu annesini başka bir erkekle gördüğünü ve annesini affedemediğini dile getirmiştir. Bağımlı olmasını bu olaydan sonra içine attığı kin ve öfke gibi duygulara bağlamıştır. Evlilik sonrası hayatında ise kendi mutluluğu için eşinin ve çocuklarının mutluluğunu ikinci plana attığını, bundan dolayı suçluluk hissettiğini söylemiştir. Suçluluk duygusunun esasında pişmanlığı ve affolunma istekliliğini artırdığını sözlerine ekleyerek bundan sonra kendi mutluluğuyla beraber ailesinin de mutluluğunu önemsediğini belirtmiştir: “Artık üzülmek istemiyorum. Ama onların da mutlu olmasını istiyorum. Suçluluk hissediyorum. Eşimi çocuklarımı ikinci plana atarak kendi mutluluğumu düşündüm" (K2). Görüldüğü gibi katılımcının sözlerinde hem evlilik öncesi hem de sonras1 yaşamında deneyimlenen "af olgusu" güçlü bir fenomen olarak kendini göstermektedir. 


\section{Yaşam Sistemindeki İlahî Tasarım İnancı olarak "Kader"}

Yaşadıkları hayatın arka planında gizlenen bir anlamın varlığını sıklıkla sorgulayan katılımcılar genellikle bu sorgulamalarını kader (K1, K2, K4) bağlamında yapmaktadırlar. Kader kavramı kendileri için Yaradan tarafindan çizilmiş yüksek bir hayat tasarımıdır. Katılımcılar, kendi seçimlerinin etkisini inkâr etmemekle beraber, iradelerinin cüz'îliğini anlamış görünümündedirler. Zira kendilerine fazla güvenmekten dolayı alkol batağına düşüklerini dile getirerek kendine güvenin insanı yanlışa sürükleyebileceğini, sınırlarını bilmek ile beraber sorumluluk alıp adım atmanın da değerini kavramış gözükmektedirler. Benzer biçimde yaşadığı değişim deneyimini kader bağlamında anlamlandırarak manevi açıdan değerli gören bir katılımcı "Allah'ın kaderine bağll yaşıyoruz. Senelerdir madde kullanan insanlarn Adlyaman-Menzil gibi manevi ortamlarda 3-5 günde değiştiklerine şahit oldum" (K4) sözleriyle belirtmektedir. Başka bir katılımcı Allah'ın, kendisine isyan mı edecek, şükür mü edecek diye insanları sınadığını" (K1) ifade ederek yaşamının anlamını kader bağlamında ele aldığını söylemektedir. Diğer bir katılımcı ise deneyimlediği yaşam olaylarında bir anlamın varlı̆̆ konusunda kafasında soru işaretleri olduğunu "Neden bu kader bana çizildi. Neden bu kadar şeyi Allah bize yüklüyor" (K2) şeklindeki sözleriyle dile getirmektedir.

\section{Duyguları kontrol etme "Nefs yönetimi"}

Alkol bağımlısı bireylerin bağımlılıklarıyla başa çıkmalarında duyguları tanıma ve kontrol edip yönetme önemli fonksiyonlar üstlenen süreçlerdir. Katılımcılar yaşam olaylarının strese eşlik eden duyguları artırdığını, sonrasında ise bu duygularla baş edebilmek için alkol kullanımına başvurduklarını belirtmektedirler. Ayrıca katılımcılar özellikle ailevi problemlerin bu sorunların başında olduğunu iletmektedirler.

Bir katılımcı bağımlılı̆̆ tanımlarken duyguları kontrol etme ve yönetme konusunda zorluk yaşanıldığına ve bu konuda başa çıkma becerileri kazanılması gerektiğine işaret eden bir yaklaşım sunmuştur: "Bağımlı kendi kendini kontrol edemeyen, özgür olamayan, bir maddeye, bir at yarışına adl ne olursa olsun ya da bir olaya vesaire bağıml olan, özgür olmayan, davranışların kontrol edemeyen, yaşamına yön veremeyen bir insandır" (K3). Aynı katılımcının "Ben 48 yaşındayım ve boşanall 7 yll oldu. Babam 'oğlum ayaklarının üzerinde dur' dedi. Hadi senin evini ayıralım işine bak dedi. Tabi gelir düzeyim düşük. Eskilerde kazandığım paraları alamıyorum. Bugün hem nafaka ödeyip hem kira ödeyip faturalar şudur

Turkish Academic Research Review - Türk Akademik Araştırmalar Dergisi https://dergipark.org.tr/tr/pub/tarr 
budur... Bu sefer stres başladı” gibi ifadelerinden stres faktörünün bağımlı birey için baş edilmesi gereken bir sorun alanı olduğu anlaşılmaktadır.

Katılımcılar duyguları kontrol edip yönetmeyi nefse ve iradeye hâkim olmak bağlamında ele almaktadırlar. Ayrıca nefsin alkol isteğine cevap vermenin kişinin kendisini, yaşamının amacını ve varoluşunun anlamını unutturduğunu belirtmektedirler:

"Şimdi bakıyorum, bir defa nefsine uyman, sadece sana mâl olan bir şey değil artık. Yaptı̆̆ımız iş nefsimizi unutturuyor. Her şeyden önce kendini, neden Allah'ın bizi dünyaya gönderdiğini, ne için yaratıldığını ve neler istediğini unutuyor insan... Bu süreçte suçluluk hissetmekten ziyade sorumluluk alıp bunu çözmem gerekir diyorum. Mesele aslında nefis meselesi. Nefsime hâkim olamıyorum, irademe hâkim olamıyorum” (K4).

Diğer bir katılımcı da benzer şekilde duyguların kontrolünü nefs kontrolü çerçevesinde değerlendirerek davranışları yönetmenin nefse uymamaktan geçtiğine işaret etmektedir:
"Eğer çok fazla tutarsanız duygularınızı kolay kolay kontrol edemiyorsanız, fiziksel olarak ne kadar güçlü olursanı olun (kalbini göstererek) şurası biraz zaylfsa... Melaneti bir şekilde ya nefsen; ya şeytana uyarak bir şekilde kullanıyoruz. Boşluktan ziyade nefsinin zayıflı̆̆ zaaflarımız var, şeytana uyuyoruz." (K3).

Alkol isteğiyle başa çıkamadığı için suçluluk duyduğunu ve bu duygusuyla başa çıkmada güçlük yaşadığı için nefsinin istek ve arzularını Yaradan’a şikâyet ettiğini söyleyen bir katılımcı "Ya Rabbim beni affet, nefsimi körlendir diyorum" (K1) diyerek duyguları kontrol etmenin alkol kullanım isteğini yönetmede önemli bir etken olduğuna vurgu yapmaktadır. Aynı şekilde gururunun, duygularını istemediği boyutta etkileyerek alkol isteğine olumsuz etki ettiğini paylaşan (K2) katılımcılar da bulunmaktadır.

Alkol kullanımı her zaman stresten değil, bilakis keyif alma, mutlu olma isteğinden de kaynaklanabilmektedir. "Devamlı dert-sıkıntıdan olmuyor, bazen keyiften de içiyorum" (K2) diyen bir katılımcı ile "Işs tatmini, hayat tatmini vs. her şey varken başladım" (K1) diyen diğer bir katılımcının ifadeleri, alkolün sadece stres gibi durumlarla başa çıkabilmek için kullanılmadığını göstermektedir. Hazzı ve mutluluğu çağrıştıran duygularla başa çıkmak alkol bağımlısı bireyler için bir ihtiyaç olarak görülmektedir: 
"Meyhanenin önünden geçerken rakının kokusu geldi burnuma. Şöyle bir baktım. 100 metre gittim. Tekrar döndüm, bu sefer 10 metre gittim. Ya git yoluna dedim. Bir duble içip birakacaktım. Bu sefer bir 70'lik rakı içtim orada. Şimdi ise ben burada (AMATEM'de) çok memnunum, tek huzur veren yer. Dışarıla alkollü olmamdansa..." (K5).

\section{Sosyal destek alma}

Alkol bağımlıları kendilerinin sosyalleşmeye duydukları ihtiyacı genellikle manevi boyutta değerlendirip bunu cümlelerine yansıtmaktadırlar. Namaz gibi topluca yerine getirilebilen ibadetler esnasında sosyallik ihtiyaçlarını giderebildiklerini sık sık vurgulamıştırlar:

"Rahatsızlıklar hat safhada olunca eskiden çalıştığım yerde tanıştığım arkadaşlarımdan beş vakit namazını kilan, yapma etme diyen çok iyi niyetli abi vard. Yolda giderken vakit namazı girerdi, o camiye gider namazını kular gelirdi ben arabada otururdum. O beni iğne oyası gibi işledi. Allah bin kere razı olsun ondan. Sonra ben namaza başladim tekrar geri döndüm. Hatta öyle ki son noktasina, tesbihine kadar. Hatta 'vay be adam bizi geçti' derdi" (K3); "Namazı arada kılardım ama bu işi cemaatle yapmak insanı çok başka boyutlara götürüyor. Yani insanın sadece kemikten ibaret olmadığın, ruhun gıdaya ihtiyacı olduğunu, bu gıdanin da cemaatle beraber olduğunu, Kuran-ı Kerim'de cemaatle beraber olun diyor. Allah-u Teâlâ sadiklarla beraber olun diyor. Biz sözümüzde durmuyoruz hiç olmazsa sözünde duranlarla beraber olalim diyoruz" (K4).

Sosyal destek alma yöneliminin esasında alkol bağımlılığıyla başa çıkmada kişinin öz düzenleme, dini/manevi bilgi ihtiyacını karşılama, kendini değerli hissetme, bağlılık duygularını tatmin etme, ilgi görme, duygularını tanıma gibi manevi ihtiyaçları karşıladığı söylenebilir. Bazı katılımcılar sosyal destek ile alkolden tamamen kurtuldukları dönemlerin olduğunu bildirirken; bazı katılımcılar ise sosyal destek sağlayan bazı grupların yanlış uygulamalarının kendisine iyi gelmediğini iletmektedirler:

"Bu konuda desteğe ihtiyacım var. Tabii bu ahlaksal destek olabilir, sohbet olabilir, kitap belki internet siteleri olabilir. Cenab-ı Allah diyor ki Allah Yeter. Araya birilerini koyuyoruz. Ama ipine sarlln dediği anda yetmediğimiz noktada birilerine mutlaka ihtiyacımız olacak" (K3); "Bir dini gruba gittim. Ticarete yöneldiklerini 
gördüm, pek ısinamadım" (K1); "Çevrem olsa alkol almam. Topluma giremiyorum, konuşmak istemiyorum. Ilgi görmek mutlu ediyor. Eşimle iletişsimim yok. Dayımın benim için manevi desteği önemli" (K2); "Ben burada (AMATEM) çok memnunum tek huzur veren yer burası. Dışarıda alkollü olmamdansa, yoksa hastane ortaminda kimse durmak istemez" (K5).

\section{Aile Bağları}

Aile bağları da sosyal destek gibi bağımlı bireylerin ihtiyaç duyduğu önemli bir manevi bakım ihtiyacıdır. Sosyallik ihtiyacının yanında kişilik, kimlik, aidiyet gibi bireyin en derin varoluşsal yönlerine de hitap eden aile beraberlikleri bağımlı bireyler için huzur ve sükûnet kaynağıdır. Ailenin bu çerçevedeki değerini anlamış görünen bir katılımcı "Her hafta sonu kzzımla görüşürüz. Anneme babama kat kat üzüntü verdim. Fiziksel anlamda, maddi anlamda... Öfkenin darbeye dönüşü̈ş halinden ziyade içiyor olduğumu bilmeleri bile onlara yeterince üzüntü veriyor. Bu konuda bana çok destek oldular. Artık hem onlar adına hem kendim adına bundan uzak durmak istiyorum" (K3) gibi ifadeleriyle alkolü bırakmayı sadece kendisi için değil ailesine olan bağlllığına değer verdiği için de istediğini ifade etmektedir.

Katılımcıların birçoğu evliliğin yaşamlarına yön verme ve yeni bir başlangıç yapma gibi ihtiyaçlarına hitap edeceğini umarak evlendiklerini fakat bu değişimin belirli bir dönem iyi geldikten sonra tekrar alkol kullanımına geri döndüklerini belirtmektedirler: Bir katılımcının "2001 yllında evlenmeye karar verdim. O dönemde alkol alışım bir süre durakladı. Sosyal hayatım değişti. Arkadaşlarımdan biraz uzak kaldım. Alkolden de biraz uzak kaldım. Evlendikten sonra yine çok nadiren sosyal içicilik vardı. Eşimle bir yere gider oturur içmezdik... Benim yalnı kalmam demek tehlikeye açık olmam demek. Ayrıca sürekli kafamı bir şeylerle meşgul ediyor olmam gerek" (K3) şeklindeki ifadelerinden yola çıkarak aile bağlarının manevi bir ihtiyaç olduğu söylenebilir.

Özellikle eş ve ailenin diğer üyeleriyle iletişimde dikkat edilmesi gereken hususlar alkolü kontrol altına almada önemli bir ihtiyaç olarak değerlendirilmektedir. Aile içi iletişimde dinî/manevî değerlerin bağlılıkları artırdığı görülmektedir:

"17 senelik evliyim. Eşim beni çok sevdiği için eşime her zaman saygl duyuyorum. Ama alkol yüzünden ayrllacak seviyeye geldik" (K5);

"Eve asla içki sokmam. Namazl güzel evime içki sokmam. Eşim çok 
kuymetli ve çok değerlidir. Çocuklarım çok ahlaklıdır" (K1); "36 yaşında eşimle tanıştım bu konuyu eşime de anlattım. Ben zamanında böyle böyleydim ama ben biraktım. Yeni bir hayata başladım. Eşim dedi, tabi olabilir dedi. O sekiz sene beni hayatımin en mutlu sekiz senesiydi" (K4).

\section{Ruhsal ve psikolojik değişimler "Gelgitler yaşamak}

İnsan tecrübesinin sürekli değişen ama bazen de aynı kalan doğasını yansıtmak ve psikolojik problemlerle uğraşan bireyler tarafindan kullanılan dili vurgulamak amacıyla kullanılan gelgit sürecine katılımcıların ifadelerinde sıklıkla rastlanmaktadır. Gelgitler yaşamalarında "Allah-u Teâla'nın kendilerine sunduğu reçeteye/emirlere dikkat etmemek, boşluk duygusu" (K4); "namazları bırakmak; nefsin zayıflığı, şeytana uyma, ailevi problemler yaşamak" (K3); "alkolü çağrıştırıcı unsurlarla temas" (K5) gibi fenomenlerin etkili olduğunu bildiren katılımc1lar manevi unsurların tekrardan temiz kalma ve bağımlılığı kontrol altına alma cesaretini diri tuttuğunu iletmektedirler.

Temiz kaldıkları süre içerinde maneviyattan uzak kaldıklarında kayma yaşadıklarını ya da kayma risklerinin yükseldiğini belirten katılımcılar manevi yaşantının; yaşamı anlamlandırma, ruhu besleme, farkındalığı artırma, dibe vurmaktan kurtarma gibi fonksiyonlarıla baş edebilme becerilerine katkıda bulunduğunu söylemektedirler:

"Insanın sadece fiziki olarak değil ruhen de gidaya ihtiyacı vardır. Bu süreç içerisinde çok bocaladım yani. Baya gelgitler yaşadım, akşam namaz kilyyorum fakat sabah böyle kesik kesik kesik çok süreçler yaşadim. O kadar güveniyordum ki kendime, bu bir hastalısa ve ömür boyu sürecekse bu hastallğın başka şeylerle doldurulması lazım. Çözmem gereken bir nokta var ki beni tutuyor. Şimdi ise bunun bir hastallk olduğunu anladiktan sonra o gelgitleri yaşamiyorum. Allah yardım etmezse ben bu hastalkkla bas edemem, kimse baş edemez” (K4); “...Ama gelgitler çoktu. Tekrar namazı bıraktım, alkole geri döndüm. En sonunda dibi gördüm. Nerede eksiklik yapıyorum? Nerede hata yapıyorum? Bunu kullanmak istemiyorum; kullandiktan sonra ertesi sabah verdiği pişmanlığı anlatamam. Özellikle secdeye gittiğinizde ă̆layarak secdeye gidiyor, ağlayarak namaz kllyyorsunuz. Ya Rabbim! Ne olur diyorsunuz... Maneviyat en önemli ihtiyaçtır, ihtiyaç listesinin en başındadır. Bir alkolik olarak eğer benim bir nebze şansım varsa inancımdan ötürü̈dür" (K3).

Turkish Academic Research Review - Türk Akademik Araştırmalar Dergisi https://dergipark.org.tr/tr/pub/tarr 
İnsanın sadece fiziki olarak değil ruhen de gıdaya ihtiyacı olduğunu belirten bir katılımcı alkol kullanarak yaşamına devam ettiği süre içerisinde çok fazla bocalama ve gelgitler yaşadığını ifade etmektedir: "Çok bocaladım yani, baya gelgitler yaşadım, akşam namaz kiliyorum fakat sabah böyle kesik kesik çok süreçler yaşadım" (K1). Ayrıca katılımcılar Yüce bir Yaratıcı inancının kapsanma, korunma ve sığınma ihtiyacına hizmet ettiğini ve böylelikle alkolle baş etmede ümidi yeşerttiğini dile getirmektedirler: "Elbette Allah Kuran'da bana gelin demiş, o da yetmemiş dostların göndermiş. Hz. Mevlâna ne olursanız olun gelin demiyor mu?" (K6); "Slğınacă̆ım başka bir yer yok" (K1).

\section{Tövbe deneyimi}

Değişim isteği alkol bağımlısı bireylerin hayatlarında çeşitli deneyimler yaşanmasına yol açmaktadır (Ceylan ve Metcalf-White, 2019). Söz konusu bu istek camiye gitme, Allah dostunu ziyaret, dini cemaatlerin sohbetlerini dinleme, tarikatların uygulamalarına dâhil olma gibi eğilimlere neden olmaktadır. Bir katılımcının, “...O arada, babam să̆ olsun, onun aracllı̆̆ ile tövbe ettim. Mahallemizdeki camiye gittim. Hocadan rica ettim. Gittim guslümü aldım, abdestimi aldım. Ben bunu bir daha kullanmayacă̆ım hocam, tövbe etmek istiyorum dedim. Sağ olsun o da yardımcı oldu. Camide tövbe ettim, 5-10 dakika beraber dua ettik. Allah'ım ben yaptıklarımdan ötürü çok pişmanım, çok günah işledim. Inşallah bir daha yapmayacağım. Kararlılıkla başladım devam ettim bir müddet" (K3) şeklindeki ifadelerinden yola çıarak tövbe niyetinin kendisine iyi geldiği, bağımlılığa karşı koruyucu bir etkisinin olduğu, iç muhasebe sürecini hareketlendirdiği söylenebilir.

Tövbe edip dönüşüm yaşamak isteyen ve bu dönüşüm sürecinde Yaradan'ın bağışlayıcılığına yönelik inancının güçlü olduğu görülen bir katılımcı 8 yıllık alkolsüz bir dönem geçirdiğini ve tövbe edip inancını koruyan birinin ömür boyu alkolden uzak yaşayabileceğini " 35 senelik hayatımda kendimi, göğü yaratanı unutmuştum. O, kulunu bağışlamak için bahane arlyor. Bir insan hata yapar, tövbe eder. Bu süreçte evlendik işte. Şu anda 3 tane çocuğum var. Tövbe ettikten sonra sekiz ylllk alkolsüz bir dönemim var. Ama bu süreci ömür boyu devam ettiren var yani. Bu süreci devam ettiren bir sürü insan var. Çok da şahit oldum" (K4) şeklindeki sözleriyle belirtmektedir. Aynı katılımcı yanına gittiği manevi bir kanaat önderinin kendisine tıbbî reçete verir gibi manevî reçete verdiğini; fakat reçeteyi aksatmaya başlayınca tekrardan alkole düştüğünü söylemektedir. Reçetede yazanları “Kötü arkadaşlardan uzak dur. Şunları yapmaya gayret et. Allah' z zikretmeye devam et. Namazını kll, abdestini al. İslam'ın gereğini söylüyor aslında. Bizim 
yapmadı̆̆ımız şeylerin yapılması gerektiğini. Benim bir sürü arkadaşım var, böyle tövbe edip de daha hiç benim gibi olmayan. Bendeki sıkıntı ben kendime biraz fazla güvendim" şeklinde ifade eden katılımcı tövbenin sürdürülebilir olması gerektiğine işaret etmektedir.

Diğer bir katılımcı ise tövbe etmeye niyetli olduğunu fakat bunun nasıl yapılacağını bilmediği için Allah’tan yardım istediğini ve Allah'ın da kendisini duyup rüyasına girdiğini ifade etmektedir. O rüyadan sonra çok farklı hissettiğini, tövbe ettiğini fakat Allah'ı ikinci defa rüyasında gördüğünde ne yapması gerektiğini bilmediğini, Allah'a sorduğunu ve Allah'ın da kendisine kıyameti gösterdiğini söylemektedir: "Ya Rabbi bunun sonu ne olacak?” Senin sayende bu işi biraktım da sonu ne olacak?” (K5). Gördüğü rüyanın etkisiyle 15 gün kadar alkol kullanamadığını sözlerine eklemektedir. Bu katılımcının tövbe niyetini taşımasının dönüşüm sürecinin başlangıcı olduğunu fakat sonrasında dönüşümü sürdürmesi için yol haritasını bilmek gerektiği hususu kendi cümlelerinden anlaşılmaktadır.

\section{Paranormal İnançlara Atıflar}

Nazar, büyü, sihir, muska gibi şeylerin var olduğuna inanan katılımcılar yaşamlarında istemedikleri değişimlerin sebebi olarak bu normal ötesi, paranormal olguları görmektedirler. Özellikle alkol bağımlılarının yaygın sorunu olan anti sosyallik, iletişim kurmayı zorlaştırmaktadır. Yakın çevresiyle ilişki kurmada zorlanmalarının nedenini paranormal güçlere atıflarda gören katılımcılar sorumluluk alıp problem çözme odaklı yaklaşımdan uzak bir görünümdedirler:

"Eve gidiyorum bunallyorum. Eş ve çocuklarla konuşmuyorum. Nazara inaniyorum. Nazar yok mu hocam, var. Muskaya inaniyordum. Ben kimseye zarar vermezken kimsenin bana zarar vermeyeceğini düşündüm. Arabamin motoru yandl. 3 kere de araba Ankara'ya gelirken arıalandl. Evi satışa çıkardım. Bir kişi bile aramadı. Hanım yüzü̆̆̈̈ kaybettikten sonra yüzüğe nazar yapıldığını düşünüyorum her şey ondan sonra oldu. Eve girdiğim an evde darlaniyorum. Tekrar eve gideceğim bakalım ne olacak?”(K1).

Yaşamındaki tüm olayların ters gittiğine dair güçlü bir inanç taşıyan bir katılımc1, "Konyada'ki hoca kafayı yemiş, dedi. Siz bu çocuğa ne yaptınız? dedi. Muska'ya inaniyorum" (K2) şeklindeki ifadeler paylaşması, onda iç görüden uzak bir başa çıkma tarzı olduğuna bir işaret olabilir. Diğer bir katılımcı ise rüyasında Allah'ı gördüğünü ifade ederek kendisinin içki içmemesi için rüyasına Allah'ın birkaç defa girdiğini dile getirmektedir.

Turkish Academic Research Review - Türk Akademik Araştırmalar Dergisi https://dergipark.org.tr/tr/pub/tarr 


\section{Tartışma ve Sonuç}

Salgın süreçleri gibi olağanüstü durumlar disiplinler arası bir psikolojik sağlık ekibinin oluşturulması, psikiyatrik tedaviler ve diğer sağlı hizmetlerinin sağlanması, çevrimiçi manevi bakım platformlarından yararlanılması, rehabilitasyon programları oluşturulması, savunmasız gruplara belirli bakımların sağlanması gibi gereksinimlerin ortaya çıktığı özel bir dönemdir.

Alkol bağımlılarının stres gibi risk unsurlarıyla baş etmelerinde manevi ihtiyaçlarının tespit edilerek manevi uygulamalara öneri geliştirilmesini amaçlayan bu çalışmada salgın sırasında bireylerin psikolojik sağlık koşulları, stres yönetimi ve alkol kullanımı açısından daha savunmasız durumda oldukları ileri sürülmektedir (Kazan Kızılkurt, 2020). Bu sebeple özellikle alkol bağımlısı bireyler, yaşadıkları psikolojik sağlık sorunları ve stresle baş etme gereksinimleri üzerinden alkole tolerans geliştirme riski yaşamaktadırlar. Her ne kadar alkol kullanımı öncelikle merkezi sinir sistemini devreden çıkarıp kişiyi rahatlatsa da sonradan insanı depresyona kadar sürükleyebilmektedir (Şahin, 2009). Söz konusu risk faktörü farklı sorunları da beraberinde getirerek alkol bağımlısı bireyin kısır bir döngüye girmesine yol açmaktadır (Gürsu, 2018: 82). Bu kısır döngüden çıkmak için birtakım ihtiyaçlar belirmektedir. Bu ihtiyaçların giderilmesi, bağımlı birey için hem dini hem de manevi anlamda önemli bulunmaktadır.

Maneviyatın olağanüstü durumlar sırasında psikolojik dayanıklılıkla pozitif bir ilişkisi olduğu bilinmektedir (Roberto vd., 2020; Yapıcı, 2020). Aşkın veya kutsal ile olan ilişki bireyin inançları, tutumları, duyguları ve davranışları üzerinde güçlü bir etkiye sahiptir. Ritüellerin uyum ve başa çıkmada etkili olduğu konusunda kanıtlar oldukça yaygındır (Spilka, 2013). Dua ve ibadet gibi dinî ritüeller bireylere stres ve hastalıklarla baş etme ve önleme (Pargament, 1997) konusunda destek sağlamaktadırlar (Çoban, 2016).

Evde kalma, kısıtlama ve yasaklamaların uygulandığg Covid-19 sürecinde katılımcıların dini ritüelleri sıklıkla yerine getirmesi geçmişte yapılan birtakım hataların telafi edilme firsatı olarak değerlendirilebilir. Ayrıca hem dünya hayatında manevi lezzetleri tatmayı hem stresten uzak kalmayı ve ahiret düşüncesine göre sonsuz bir mutluluk yurduna ulaşabilmeyi sağlayabilir. $\mathrm{Bu}$ bakış açısı alkol istekliliğine karşı koruyucu ve önleyici bir fonksiyon üstlenebilir.

Affedilme ve affedebilme gibi af olgusu çevresinde ortaya çıkan özel ihtiyaçlar da katılımcılar tarafından manevi ihtiyaçlar kapsamında ele alınmaktadır. Aynı şekilde aile bağlarını güçlendirme, sosyal destek alma, tövbe deneyimleri, 
gelgitler yaşama, yaşam sistemindeki İlahî tasarımı sorgulama gibi katılımcıların ifadelerinden çıkan temalar, madde bağımlısı bireylerin manevi ihtiyaçları kapsamında yapılan Ceylan'ın (2019) çalışmasında da dile getirilmiştir. Paylaşılan bu temalarla ilgili zihinsel ve duygusal arka planda yaşanan çıkmazlar çözüme kavuşturulmayı bekleyen ve maneviyatla büyük ölçüde ilişkili olan hususlardır.

Katılımcıların ifadelerine göre duyguları yönetmeyi öğrenmek aslında nefis terbiyesini öğrenmektir. Nefsin eğitimi ise birtakım ritüelleri ve davranışları sergileyerek mümkün olabilir. Nitekim davranışları kontrol etmek, duyguları kontrol etmekten daha kolaydır. Bununla beraber duyguları kontrol etmeye çalışmak da alkol bağımlılarının başa çıkma becerilerine yönelik manevi bakım uygulamaları kapsamında ele alınabilir (Witkiewitz, vd., 2016). Bu bağlamda bireyin iç dünyasında rehber rolü üstlenen duyguları tanımak alkol bağımlılığını kontrol altına almada önemli bir aşamadır denilebilir. Zira adı konulan ve tanınan bir duygu daha iyi yönetilebilir.

Alkol kullanımı, nefsin mutlu olma ve acıdan kaçma gibi en temel iki arzusuna hizmet etmektedir. $\mathrm{Bu}$ çerçevede manevi boyutta ruhun lezzet alma düşüncesi ve başa çıkma becerilerini destekleyen sabır değeri manevi bakım çalışmalarına dâhil edilebilir. Zira manevi bakım her zaman dini inançların bir parçası olmakla birlikte sağlık ve refahın bütünleyici bir boyutudur (Roman vd., 2020).

Diğer taraftan AMATEM'e dini ritüellerin yerine getirildiği bir ibadet merkezi nazarıyla bakılabilir. Zira sıklıkla gelgitler yaşadıklarını ileten katılımcıların uzun süreli alkolden uzak kalma hedefi her zaman ulaşılabilir değildir. Yaşamda sıkıntılar birçok kez gelir ve gider, önemli olan bireyin problemlerle başa çıkabilmesi ile ilgili girişimleridir (Bağ, 2019). Bu kapsamda alkolden uzak kalma aralıklarını artırmak kısa vadeli küçük çözümler arasında değerlendirilebilir. Bu bağlamda İslam düşüncesindeki istiğfar kavramı bu kısa aralıkların sıklığına ve süresine olumlu etkide bulunarak başa çıkma süreçlerine katkıda bulunabilir.

İslam dininde tövbe düşüncesi ve uygulamaları ibadet sayıldığı için, deneyimlenen her bir yaşam olayında "bir halden başka bir hale geçme (tövbe/dönüşüm)" niyeti gözetilirse bağımlı bireyin alkolden uzak kalma yolculuğunda her bir duygusu, düşüncesi ve eylemi ibadet kapsamında değerlendirilebilir. Maddi veya manevi şekilde ayrım yapmadan yaşama ilişkin tüm ögelere böylelikle manevi bir anlam yükleyebilir, tövbe niyeti ile sürekli manevi bir hayat yaşayabilir. Bu bağlamda İslam inancındaki tövbe edenlerin kötülüklerinin

Turkish Academic Research Review - Türk Akademik Araştırmalar Dergisi https://dergipark.org.tr/tr/pub/tarr 
iyiliklere dönüştürüleceği düşüncesi (Furkan Suresi, 25: 70) de bağımlı birey için değişim azmi ve ümidi (DiClemente, 2016) verebilir.

Alkol bağımlısı bireyler için nefsin isteklerini kontrol etmek, dini bir ritüel olarak görülmektedir. Bu açıdan bağımlı bireyler AMATEM'i bir “ibadet merkezi” olarak görebilecekleri gibi “dönüşüm yeri, tövbe merkezi veya nefis eğitim merkezi” olarak da değerlendirebilirler. Beynin tuzaklarından uzak durmak aynı zamanda nefsin kötü veya olumsuz arzularından uzak durmakla büyük ölçüde yakın anlamlıdır. Onlara göre nefsin arzularının farkında olmak, onu eğitmek ve yönetmek alkol kullanımından uzak kalmayı sağlamaktadır. Bununla beraber duyguları tanımak, yönetme becerisi kazanmak ve kontrol etmek (Ceylan, 2020) de bahsi geçen nefsin arzularıyla başa çıkmayla benzerlik göstermektedir (Suud vd., 2020). Nitekim İslâm dininde alkollü içkilerin haram kılınması kişinin aklının, malının, neslinin ve canının korunması ve onlara hürmet edilmesi içindir (Mâide, 5:90-91). Kur'an-1 Kerim'deki söz konusu ayetle alkolden uzak kalınması gerektiğine, alkol bağımlılığına yönelik koruyucu yaklaşımların önemine dikkat çekilmektedir.

Katılımcıların yaşam olaylarıyla başa çıkma kapsamında dini inançlarla ilişkili olarak sunduğu sihir, muska, büyü gibi paranormal inançlar; insanoğlunun gerçeği olduğu gibi kabullenmesine karşı bir direnç olarak değerlendirilebilir. Paranormal inanç ve davranışları tercih edilir kılan ve onlara süreklilik kazandıran şey, kişiye başa çıkma sürecini desteklemek gibi bir faydasının olduğu düşüncesidir (Ayten, 2017: 47, 49). Bahsi geçen mistik hezeyanların genellikle içgörü eksikliğinden kaynaklandığı bilinmektedir (Şirin, 2006). Sorumluluk duygusunu da azaltabilen söz konusu paranormal inançların mistik hezeyanları artırıcı olduğu ve dinin içinde yer almadığına ilişkin kanıta dayalı veriler, alkol bağımlıları için değişim niyetini kuvvetlendirici ve başa çıkma becerilerini artırıcı bakım çalışmalarında uygulanabilir.

Sonuç olarak katılımcıların deneyimlerinden çıkan ve ulaşılan bulguların arka planında yatan anlamlar yorumlanarak "dini ritüeller, af olgusu, yaşam sistemindeki İlahî tasarım inancı olarak kader, duygularl kontrol etme "nefs yönetimi”, sosyal destek almak, aile bă̆ları, ruhsal ve psikolojik değişimler "gelgitler yaşamak", tövbe deneyimi, paranormal inançlara atıflar" isimli temalara ulaşılmıştır. Elde edilen bulguların betimleyici fenomenolojik analizi sonrası ortaya çıkan temalar "manevi ihtiyaçlar" olarak değerlendirilip manevi bakım uygulamalarında gözetilebilir. Covid-19 salgını gibi olağanüstü durumlarda önemi daha da ön plana çıkan manevi bakım uygulaması, bahsi geçen ihtiyaçlara yönelik hizmet sağlayabilir. 


\section{Kaynakça}

Akgün, O. (2020). COVID-19 Salgını döneminde Türkiye'de alınan idari kararların salgının önlenmesindeki etkisinin değerlendirilmesi. Avrasya Sosyal ve Ekonomi Araştırmaları Dergisi, 7(7), 201-228.

Ayten, A. (2017). Mutluluğun peşinde. Çamlıca Yayınları.

Bağ, B. (2019). Ruh sağlığı ve psikiyatri hemşireliği uygulamalarında gelgit modeli. Psikiyatride Güncel Yaklaşımlar, 11(4), 547-560.

Calina, D., Hartung, T., Mardare, I., Mitroi, M., Poulas, K., Tsatsakis, A., Rogoveanu, I., \& Docea, A. O. (2021). COVID-19 pandemic and alcohol consumption: Impacts and interconnections. Toxicology Reports, 8, 529-535.

Ceylan, İ. (2020). Madde bağımlısı bireylerin değişim sürecindeki farkındalık düzeylerine varoluşçu/manevi yaklaşım. Türk Manevi Danışmanlık ve Rehberlik Dergisi, 2, 97-134.

Ceylan, İ. (2021). Bă̆ımlılık değişim ve maneviyat. Nobel Yayıncılık.

Ceylan, İ., \& Metcalf-White, L. (2019). Perception of spirituality among substance addicts with incarceration experience: A phenomenological study. Spiritual Psychology and Counseling, 4(3), 201-218.

Chodkiewicz, J., Talarowska, M., Miniszewska, J., Nawrocka, N., \& Bilinski, P. (2020). Alcohol consumption reported during the COVID-19 pandemic: The initial stage. International Journal of Environmental Research and Public Health, 17(13), 4677.

Clay, J. M., \& Parker, M. O. (2020). Alcohol use and misuse during the COVID-19 pandemic: A potential public health crisis? The Lancet Public Health, 5(5), 259.

Çoban, M. (2016). Uyuşturucu madde bağımlılı̆̆ı ile mücadelede manevi danışmanlık ve rehberlik uygulamalarının yeri ve önemi: İstanbul örneği. A. Ayten, M. Koç, N. Tınaz, (editörler) Manevi Danışmanlık ve Rehberlik Cilt-II içinde (ss. 127-141). DEM.

De Backer, L. M. (2021). COVID-19 lockdown in South Africa: Addiction, Christian spirituality and mental health. Verbum et Ecclesia, 42(1), 1-9.

DiClemente, C. C. (2016). Bağımlılık ve değişim. Nobel Yayıncılık.

Fardin, M. A. (2020). COVID-19 epidemic and spirituality: A Review of the benefits of religion in times of crisis. Jundishapur Journal of Chronic Disease Care, 9(2).

Gürsu, O. (2018). Bağımlılık ve din: Nöropsikolojik bir yaklaşım. DEM Yayınları.

Turkish Academic Research Review - Türk Akademik Araştırmalar Dergisi https://dergipark.org.tr/tr/pub/tarr 
Kazan Kızılkurt, Ö. Dilbaz, N. (2020). COVID-19 pandemisinde bağımlılık. B. Coşar (ed.), Psikiyatri ve COVID-19 içinde (ss. 59-651). Türkiye Klinikleri.

Knopf, A. (2020). Alcohol and isolation: Experts comment on drinking behavior during COVID-19. Alcoholism \& Drug Abuse Weekly, 32(13), 1-4.

Kur'ân-ı Kerîm, Diyanet İşleri Başkanlığı Yayınları, 2010.

Lechner, W. V., Laurene, K. R., Patel, S., Anderson, M., Grega, C., \& Kenne, D. R. (2020). Changes in alcohol use as a function of psychological distress and social support following COVID-19 related University closings. Addictive Behaviors, 110, 106527.

Pargament, K. I. (2001). The psychology of religion and coping: Theory, research, practice. Guilford Press.

Roberto, A., Sellon, A., Cherry, S. T., Hunter-Jones, J., \& Winslow, H. (2020). Impact of spirituality on resilience and coping during the COVID-19 crisis: A mixed-method approach investigating the impact on women. Health Care for Women International, 1-22.

Roman, N. V., Mthembu, T. G., \& Hoosen, M. (2020). Spiritual care -'A deeper immunity'- A response to Covid-19 pandemic. African Journal of Primary Health Care \& Family Medicine, 12(1), 2456.

Spilka, B. (2013). Dinî pratik, ritüel ve dua. İ. Çapçıŏlu ve A. Ayten (Editörler). Din ve maneviyat psikolojisi-yeni yaklaşımlar ve uygulama alanlart içinde (ss. 157-180). Phoenix.

Suud, F. M., Gaffar, A., Rouzi, K. S., \& Chaer, M. T. (2020). The role of Islamic counselling in pandemic COVID 19: A conceptual study for developing positive emotion of parents and children. Jurnal Konseling Religi, 11(1).

Şahin, N. H. (2009). Stresle başa çıkma yolları: Olumlu bir yaklaşım. Türk Psikologlar Derneği Yayınları.

Şirin, T. (2006). Metafizik varlıklardan cinlere inancın psiko-sosyal boyutları (Yayımlanmamış Yüksek Lisans Tezi). Marmara Üniversitesi Sosyal Bilimler Enstitüsü.

Witkiewitz, K., McCallion, E., \& Kirouac, M. (2016). Religious affiliation and spiritual practices: An examination of the role of spirituality in alcohol use and alcohol use disorder. Alcohol Research: Current Reviews, 38(1), 55.

Yapıcı, A. (2020). Zor zamanlarda dindarlık ve maneviyatın ruh sağlığıyla ilişkisi. Bayram Demirtaş (ed.). Salgın Zamanında Manevi Destek içinde (ss. 35-47). Diyanet İşleri Başkanlığı Yayınları.

Yıldırım, A., \& Şimşek, H. (2008). Nitel araştırma yöntemleri. Seçkin Yayınc1lı. 